\title{
MIKROHULLÁMÚ KEZELÉSEK HATÉKONYSÁGVIZSGÁLATA ÉS DIELEKTROMOS MÉRÉSEK ALKALMAZÁSI LEHETŐSÉGEI SZENNYVÍZ ÉS ISZAPKEZELÉS SORÁN
}

\section{Beszédes Sándor - Kovács Róbertné - Keszthelyi-Szabó Gábor - Hodúr Cecilia}

\begin{abstract}
Absztrakt: A mikrohullámú energiaközléses múveletek az élelmiszeripar, a vegyipar, a biotechnológia és a környezetvédelmi eljárások gyakorlatában is egyre inkább elterjednek. A mikrohullámú kezelési eljárások hatékonyságának részletesebb elemzése és a léptéknövelés azonban szükségessé tenné a folytonos anyagáramú kezelörendszerekben végzett kísérletek végrehajtását. A kutatási munkánk során szennyvizek és iszapok biológiai hasznosíthatóságát befolyásoló szerkezeti és biológiai lebonthatósági változásokat vizsgáltuk folytonos anyagáramú mikrohullámú kezelések esetében. A vizsgálataink emellett kiterjedtek a mikrohullámú sugárzás hökeltési hatékonyságát meghatározó dielektromos jellemzök mérésére is.
\end{abstract}

Abstract: Microwave applications have been more and more widely used in food technologies, biotechnology, chemical industry and environmental technique, as well. Detailed analysis of the efficiency and scale-up of microwave processes has been necessitated to carry out experiments in continuously flow microwave equipment. In our research work a continuously flow microwave reactor was applied for pre-treatments of sludge and wastewater. We focused on the investigation of change in physicochemical structure and biodegradability of wastewater and sludge which are considered as main factors determining the further biological utilization and valorisation of waste streams. Our research was extended to measure the dielectric parameters which influence mainly the heat generation efficiency of microwave irradiation.

Kulcsszavak: mikrohullám, dielektromos paraméterek, szennyvíz, iszap

Keywords: microwave, dielectric parameters, wastewater, sludge

\section{Bevezetés}

A szennyvíz- és szennyvíziszap kezelés során egyre nagyobb hangsúlyt kapnak azon eljárások, amelyekben a szennyezőanyagok eltávolítása, vagy mobilitásuk csökkentése mellett, illetve helyett, egyes szerves és szervetlen komponensek hasznosítása történik. Környezetvédelmi megfontolások alapján a kezelési eljárások közül azokat célszerü elönyben részesíteni, amelyek önmagukban csekély környezetterheléssel és minimális hulladékproduktummal járnak. A szennyvizek és szennyvíziszapok esetében, különösen ha azok kommunális, vagy élelmiszeripari eredetủek, az anaerob fermnetáció az egyik legelönyösebb technológia, mivel a biológiai stabilizálás mellett energiahordozó is keletkezik a folyamatban (Appels et al., 2008).

A kommunális, mezögazdasági és élelmiszeripari eredetü szennyvizek és iszapok elméleti biológiai lebonthatósága jó, azonban a képződési helyükön, illetve a további szennyvízkezelés során adagolt egyes vegyületek a valós körülmények közötti lebonthatóságot korlátozzák. Az iszapok esetében a vízteleníthetőség javítása, illetve a szennyvizek esetében is a biológiai bonthatóság javítása céljából többféle elökezelést alkalmaznak. Ezek közül az utóbbi években egyre több kutatás 
foglalkozik a mikrohullámú energiaközlés, mint előkezelési eljárás hatékonyságának elemzésével.

Az elektromágneses spektrum mikrohullámú frekvencia tartománya nagy nedvességtaratlmú anyagok esetében intenzív hökeltésre alkalmas. A többkomponensü rendszerekben, ha a komponensek dielektromos tulajdonságai különbözöek, ún. szelektív felmelegedés tapasztalható. A szennyvíziszapok esetében megállapították, hogy a mikrohullámú előkezelések alkalmazásával az iszappelyhek gyors és hatékony dezintegrációja idézhetô elő, az egyes szerves vegyületecsoportok vízoldhatósága fokozható, amely hatások például a biogázkitermelési mutató javulását okozzák, illetve az anaerob körülmények közötti lebontás ütemét gyorsítják (Beszédes et al., 2009). A mikrohullámú elökezelés egyes fermentációs és enzimes folyamatok hatékonyságának növelésére is alkalmas (Kapcsándi et al., 2016).

Az eddigi ígéretes, elsősorban laboratóriumi léptékü batch kísérletekből nyert eredmények azonban egyre inkább szükségessé teszik, hogy a mikrohullámú energiaközléses műveletek hatékonyságát folytonos anyagáramú rendszerekben is vizsgálják (Estel et al., 2017). Az iszapkezelés esetében az eddigi biogázkitermelési vizsgálatokat elsősorban kommunális eredetủ, biológiai tisztítóból elvezetett fölösiszap alapanyaggal végezték. A mikrohullámú kezelési módszer alkalmazhatóságának megítélése érdekében szükséges lenne más típusú szennyvíz és iszap vizsgálatokba való bevonása, illetve a másodlagos tisztítási fokozatból származó iszapok mellett primer iszapok kezelése is.

A mikrohullámú anyagkezeléshez kapcsolódó kutatások során a dielektromos mérések hasznos eredményekhez vezethetnek. A dielektromos jellemzők egyrészt a mikrohullámú energiaközlés hőkeltési hatékonyságát határozzák meg, másrészről potenciálisan alkalmasak lehetnek nemcsak a mikrohullámú kezelések, hanem más típusú - termikus, kémiai vagy biológiai - kezelési eljárások közben az anyag szerkezetében végbemenő változások detektálására, a kezelési folyamatok kontrollálására is (Lievonen-Roos, 2003).

A szakirodalomban különböző mezögazdasági és élelmiszeripari alapanyagok és termékek dielektromos jellemzőinek hömérséklettől és frekvenciától való függésének vizsgálatával már évtizedek óta foglalkoznak (Venkatesh-Raghavan, 2004). A dielektromos méréseket használták már különböző fermentációs folyamatok nyomon követésére is (Velazquez-Varela et al., 2013). A szennyvizek és iszapok dielektromos jellemzőinek meghatározására vonatkozó eredmények azonban az eddigiekig csak csekély számban állnak rendelkezésre, ezen hiányosságok újabb kutatási területeket jelölnek ki.

Mindezek alapján a főbb kutatási célkitüzéseink a következőek voltak:

- A mikrohullámú előkezelések hatékonyságvizsgálata folytonos anyagáramú kezelörendszerben

- A mikrohullámú előkezelés hatásának vizsgálata élelmiszeripari eredetủ szennyvizek és iszapok biogáztermelésére

- Dielektromos állandó értékének meghatározása különböző élelmiszeripari szennyvíztípusok esetén 


\section{Anyag és módszer}

A vizsgálatainkhoz élelmiszeripari eredetủ szennyvíz és iszap mintákat használtunk fel. A mikrohullámú elökezeléseket egy folytonos anyagtovábbítású toroid üregrezonátoros kezelőegységben végeztük, amelyben az anyagmozgatást perisztaltikus pumpával biztosítottuk. A $2450 \mathrm{MHz}$ frekvencián sugárzó magnetron teljesítménye 100-700 W tartományon belül fokozatmentesen volt változtatható.

A biogáz termelődést mezofil hőmérséklettartományban $\left(37 \pm 0,5^{\circ} \mathrm{C}\right)$, folyamatosan kevertetett $250 \mathrm{~mL}$-es térfogatú anaerob laboratóriumi lombikreaktorokban vizsgáltuk. A termelődő biogáz térfogatát a légmentesen zárt, OxiTop-C manometrikus mérőfejekkel felszerelt lombikokban mért nyomásnövekedés alapján számítottuk. A minták beoltására egy mezofil hőmérsékleten üzemelő rothasztó iszapját használtuk 10\%-os koncentrációban.

A dielektromos állandót az SZTE Mérnöki Kar Folyamatmérnöki Intézetében fejlesztett átfolyásos rendszerú dielektromos mérörendszerrel határoztuk meg 2450 $\mathrm{MHz}$ frekvencián. A dielektromos állandó meghatározásánál a mérőtápvonalban a haladó irányú és visszavert elektromágneses hullámok egymásra hatása következtében kialakuló állóhullámok amplitúdójával arányos feszültségjeleket, illetve ezek maximum és minimum helyeinek eltolódását (fázistolás) detektáltuk.

A reflexiós tényezöt $(\Gamma)$, a detektordiódák négyzetes karakterisztikáját figyelembe véve, az állóhullám maximális és minimális amplitúdójához tartozó feszültségjelekből $\left(U_{\max }\right.$, ill. $\left.U_{\min }\right)$ adtuk meg.

$$
\Gamma=\frac{\sqrt{\frac{U_{\max }}{U_{\min }}}-1}{\sqrt{\frac{U_{\max }}{U_{\min }}}+1}
$$

A mért feszültségjelekből továbbá a fázisszög $(\varphi)$ és a veszteségszög $(\delta)$ is számítható.

$$
\begin{gathered}
\varphi=\frac{\pi}{2} \operatorname{arctg}\left(\frac{U_{\max }}{U_{\min }}\right) \\
\delta=2\left\{\operatorname{arctg}\left[\frac{|\Gamma| \sin \varphi}{1-|\Gamma| \cos \varphi}\right]-\operatorname{arctg}\left[\frac{|\Gamma| \sin \varphi}{1+|\Gamma| \cos \varphi}\right]\right\}
\end{gathered}
$$

A reflexiós tényezö, a fázis-, illetve veszteségszög ismeretében a dielektromos állandó $\left(\varepsilon^{\prime}\right)$ a (4) összefüggéssel adható meg.

$$
\varepsilon^{\prime}=\frac{1}{\sqrt{1+\operatorname{tg} \delta^{2}}} \cdot\left(\frac{1+|\Gamma|^{2}+2|\Gamma| \cos \varphi}{1+|\Gamma|^{2}-2|\Gamma| \cos \varphi}\right)
$$

\section{Eredmények és értékelésük}

A kutatás során az egyik célkitúzésünk a mikrohullámú elökezeléseknek az iszapok rothaszthatóságára gyakorolt hatásának vizsgálata volt. Az eddig rendelkezésre álló 
szakirodalmi eredmények nem egyértelműek annak vonatkozásában, hogy a mikrohullámú energiaközléssel végzett iszapkezeléseknél a teljesítményszint önmagában, vagy a mikrohullámú teljesítmény és kezelési idő szorzataként értelmezhető közölt energia befolyásolja-e nagyobb mértékben a biogázfejlődés folyamatát.

$\mathrm{Az}$ általunk használt folytonos anyagáramú kezelörendszerben ezért a térfogatáram és a mikrohullámú sugárzást generáló magnetron teljesítményének megfelelő megválasztásával olyan iszap előkezelési beállításokat alkalmaztunk, amelyeknél egy adott közölt mikrohullámú energia három különböző teljesítményszint (418 W-536 W-700 W) beállitásával biztosítható.

A mezofil hőmérséklettartományban végzett rothasztási tesztek eredményei alapján megállapítható, hogy a folytonos anyagáramú mikrohullámú előkezelések hatására a fajlagos biogáz-kitermelési mutató javult. A nyers iszap eredeti kb. 220 $\mathrm{cm}^{3} \mathrm{~g}^{-1}$ biogáz-kitermelési mutatója a mikrohullámú energiaközlést követően a 450 $\mathrm{cm}^{3} \mathrm{~g}^{-1}$ értéket is meghaladta (lásd: 1 . ábra). A saját, húsipari iszapra vonatkozó kísérleti eredményeink egyeznek a szakirodalomban leírt föbb megállapításokkal, miszerint a mikrohullámú előkezelés a kommunális eredetű szennyvíziszapok biológiai lebonthatóságát, ezen belül a rothaszthatóságát javítja (Ahn et al., 2009).

\section{1. ábra: A mikrohullámú kezelés energiaintenzitásának és} teljesítményszintjének hatása a biogáz-kitermelési mutatóra

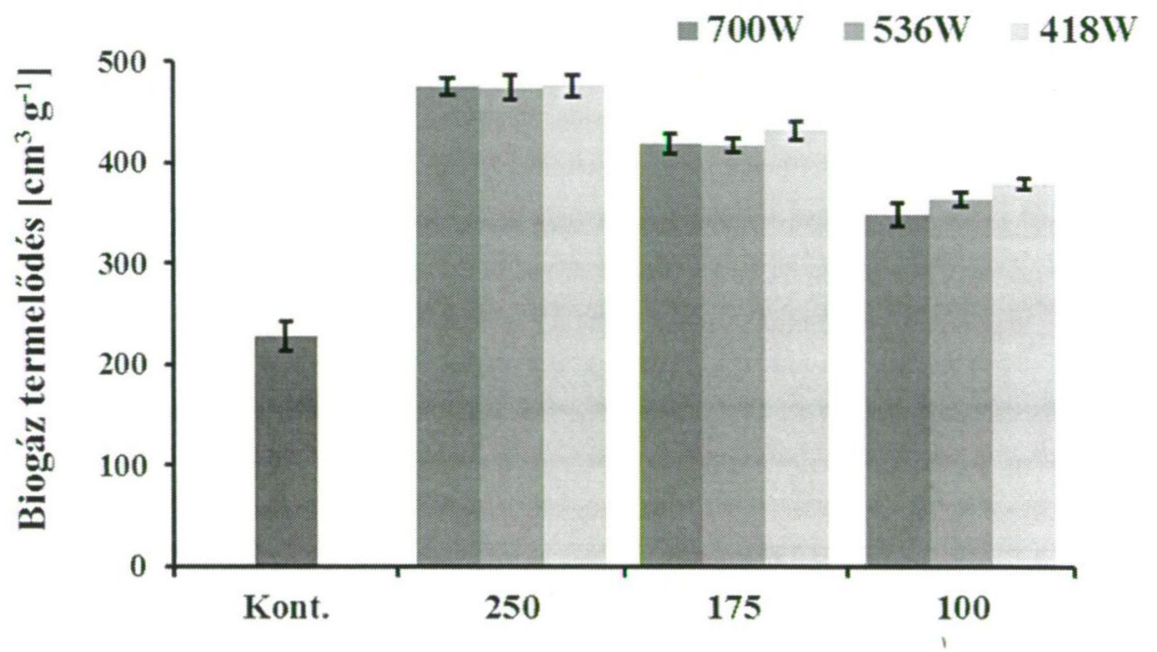

Közölt mikrohullámú energia $\left[\mathrm{kJ} \mathrm{dm}^{-3}\right]$

Az anaerob fermentációs tesztek alapján megállapítható, hogy a húsipari eredetű szennyvíziszap esetében a $2450 \mathrm{MHz}$ frekvenciájú mikrohullámú sugárzás alkalmazásakor a biogáz termelődését elsősorban az energiaközlés mértéke határozta meg. A nagyobb mértékü energiaközlés $\left(250 \mathrm{~kJ} \mathrm{dm}^{-3}\right)$ esetében a vizsgált tartományon belül a teljesítményszint változása nem gyakorolt számottevő hatást az 
iszap biogáz termelésére. A kisebb mértékü energiaközlés $\left(100 \mathrm{~kJ} \mathrm{dm}^{-3}\right)$ esetében azonban a teljesítmény csökkentése kismértékben javította a kitermelési mutatót.

$\mathrm{Az}$ alacsony mértékü energiaközlés esetében a csökkenö teljesítményszint kedvező hatását feltehetőleg a kezelötérben való tartózkodási idő növekedése okozza.. Ezek alapján tehát a kis energiaintenzitású elökezelések esetében a mikrohullámú teljesítményszint befolyásolja a biogáz produktumot, az alacsonyabb teljesítményszinttel párosuló hosszabb kezelési idő kedvezőbb az anaerob fermentáció szempontjából, azonban a nagyobb energiaintenzitású kezeléseknél a teljesítményszint hatása már elhanyagolható.

A rothasztást megelőző kezelések hatékonyságának megítélése szempontjából azonban az elérhető biogázproduktum mellett az előkezelések energiaszükségletét is figyelembe kell venni. A mikrohullámú iszap előkezelés energetikai hatékonyságának jellemzése céljából ezért egyszerüsített energiamérleget számítottunk, amelyben az előkezelés hatására termelödött biogáz energiatartalmának és kezelések során közölt energiának a különbségét adtuk meg, egyégnyi térfogatú anyagra vonatkoztatva.

Az eredmények alapján megállapítható, hogy a nagyobb energiaintenzitású kezelések ugyan nagyobb biogáz produktum elérését tették lehetővé, azonban a kezelések saját energiaszükséglete ebben az esetben már több esetben meghaladta a többlet biogáz energiatartalmát (lásd: 2. ábra).

A kezelések során befektetett energiának, és az ennek hatására képződő biogáz által képviselt többlet energia alapján értelmezett megtérülés szempontjából az alacsonyabb energiaintenzitású előkezelések kedvezőbbek. Figyelembe véve az anaerob fermentáció során végbemenő szervesanyag eltávolítás hatékonyságát (iszapstabilizálás), illetve az ezzel összefüggỏ teljes biogáz termelést, valamint az előkezelések során biztosítandó teljesítményszint eléréséhez szükséges berendezés teljesítményt, az általunk vizsgált paraméter párosítások közül az $536 \mathrm{~W}$ mikrohullámú teljesítményszinttel történő $175 \mathrm{~kJ} \mathrm{dm}^{-3}$ intenzitású energiaközlés elökezelésként való alkalmazása javasolható.

A kutatásunk egy másik fázisában eltérő eredetü és összetételü szennyvizek dielektromos jellemzöinek meghatározásával foglalkoztunk. A dielektromos méréseket egy átfolyó rendszerü mérörendszerrel végeztük annak céljából, hogy dielektromos jellemzők hỏmérsékletfüggése mellett megvizsgáljuk a minta átáramlási térfogatáramnak a polarizációs jelenségekre, és ezáltal a mérhető dielektromos állandóra gyakorolt hatását is. A kísérletekben alkalmazott kétféle húsipari és tejipari eredetü - szennyvíz mintára mérhető dielektromos állandó értékét tekintve megállapítható, hogy a szakirodalomban a tiszta vízre közölt eredményekkel összhangban, a hömérsékletnövelés hatására csökkenö tendencia tapasztalható (lásd 3. és 4. ábra). A víznél nagyobb dielektromos állandót a szennyvízben lévő ionok és poláros vegyületek okozzák, mivel ezek polarizálhatósága könnyebb, mint a vízmolekuláké (Brodie et al., 2014). 
2. ábra: A mikrohullámú előkezelések energiamérlege

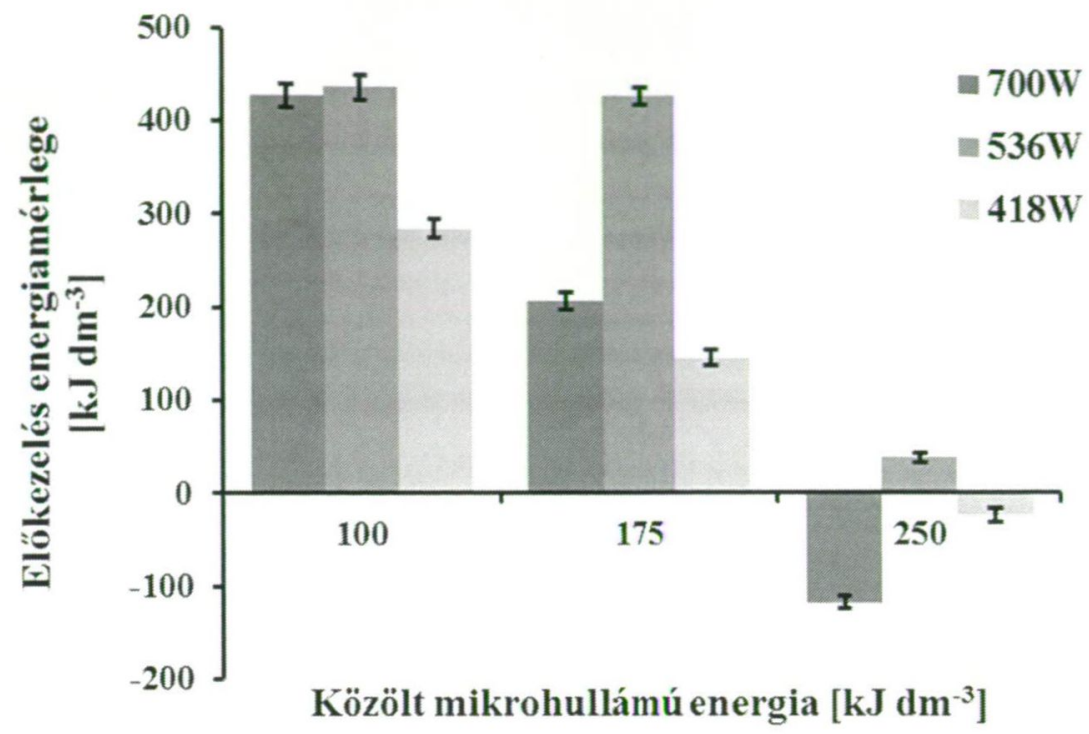

3. ábra: Dielektromos állandó ( $\left.\varepsilon^{\prime}\right)$ hőmérséklet és térfogatáram függése húsipari szennyvíz esetében

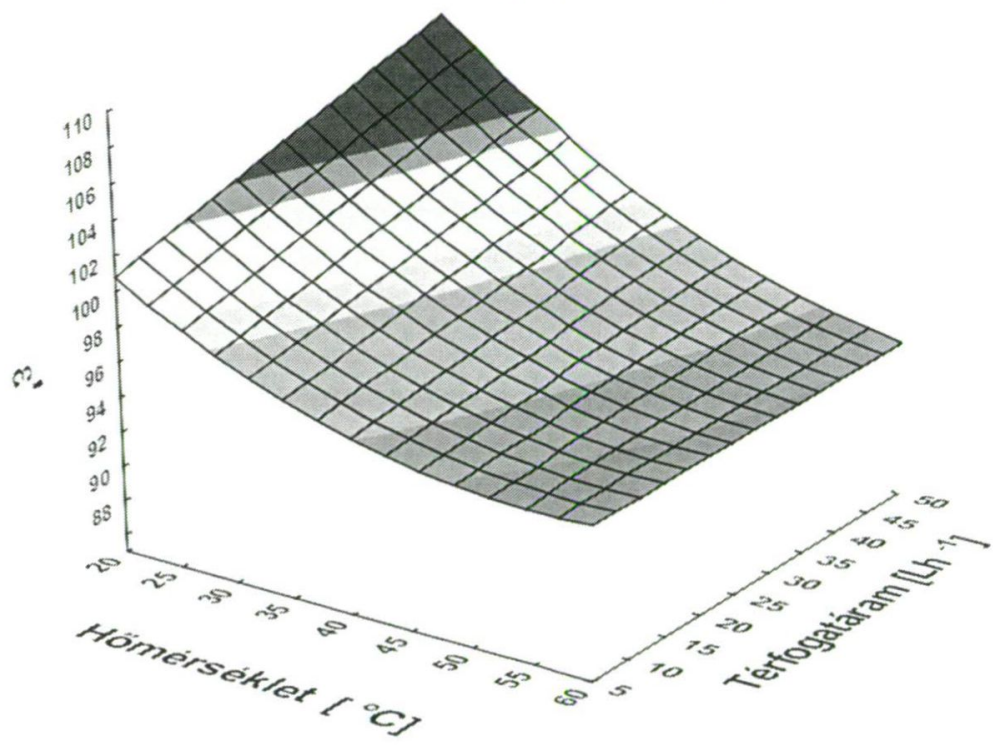




\section{4. ábra: Dielektromos állandó ( $\left.\varepsilon^{\prime}\right)$ hőmérséklet és térfogatáram függése tejipari szennyvíz esetében}

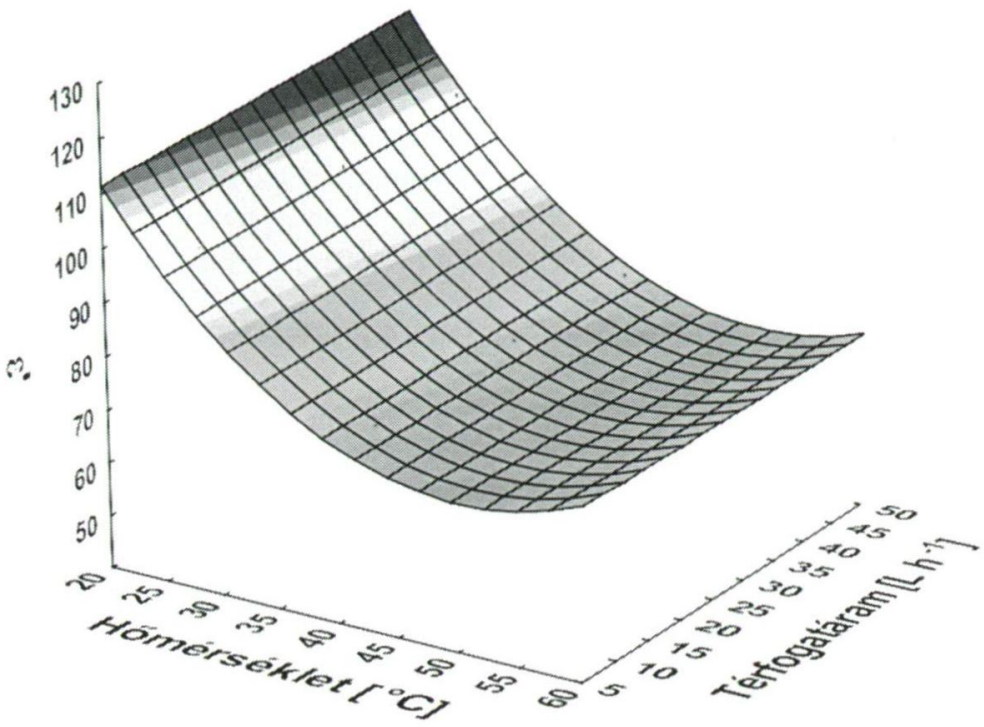

Megállapítható, hogy a magasabb szervesanyag és ionkoncentrációval rendelkező húsipari szennyvíz dielektromos állandója $\left(\varepsilon^{\prime}\right)$ nagyobb, mint a tejipari szennyvízé. A dielektromos állandó értéke azonban önmagában nem alkalmas a szervesanyag terhelés mennyiségi jellemzésére, mivel a dielektromos paraméterek a szerves komponensek koncentrációja mellett azok szerkezetétől is függenek, míg a környezetvédelmi gyakorlatban és a környezetvédelmi bírságok megállapításánál összegparaméterek (például kémiai oxigénigény, biokémiai oxigénigény) használatosak.

$\mathrm{Az}$ eredményeink alapján továbbá megállapítható, hogy a fázistolásos módszerrel mérhető dielektromos állandónak a térfogatáramtól való függése csak alacsony $\left(20-35^{\circ} \mathrm{C}\right)$ hỏmérséklettartományban tapasztalható. A térfogatáram függés mértéke a nagyobb szervesanyag és sótartalmú húsipari szennyvíz esetében jelentősebb (3. ábra).

A folyadékoknál az alacsonyabb hőmérséklet kisebb viszkozitást eredményez, amely a polarizálhatóságot és az ionoknak a nagy frekvenciával változó polaritású térben való migrációját is befolyásolja.

Alacsonyabb hőmérsékleten továbbá a mérendő minta homogenitása is nehezebben biztosítható. Ebben az esetben a minta áramoltatása, és a térfogatáram növelése befolyásolja a mérhető látszólagos dielektromos állandó értékét. Ezek a különbségek azonban a hömérsékletnövekedés hatására mérséklődnek, különösen a kisebb oldott és oldhatatlan anyag koncentrációjú szennyvizeknél. 


\section{4. Összegzés}

A kutatómunkánkban a mikrohullámú energiaközlés, mint szennyvíz- és iszap előkezelési módszer hatékonyságának vizsgálatával foglalkoztunk. Az eredményeink alapján megállapítható, hogy a folytonos anyagáramlású mikrohullámú előkezelések alkalmasak a mezofil anaerob fermentációs folyamatban képződő biogáz mennyiségének növelésére, a növekmény mértéke a kezelési paraméterek közül elsősorban a közölt mikrohullámú energia által meghatározott.

$\mathrm{Az}$ energiahasznosulás vizsgálata során megállapítottuk, hogy a nagyobb energiaintenzitású és magasabb teljesítményszintü előkezeléseket követően, a rothasztás során képződő biogáz mennyisége több, azonban az intenzitás növeléséből adódó nagyobb kezelési energiaszükségletet egy határon túl a biogáz többlet már nem tudja kompenzálni, vagyis az energiahatékonyság romlik.

A mérési eredményeink alapján látható, hogy a dielektromos állandó értékét, különösen nagy szervesanyag tartalmú szennyvizek esetében, nemcsak a hömérséklet, hanem az átfolyó rendszerü mérési elrendezés során a minta térfogatárama is befolyásolhatja.

\section{Köszönetnyilvánítás}

A kutatómunka az MTA Bolyai János Kutatási Ösztöndíj és az Emberi Erőforrások Minisztériuma UNKP-17-4 kódszámú Új Nemzeti Kiválóság Programjának támogatásával készültt.

\section{Irodalomjegyzék}

Ahn, J. H., Shin, S. G., Hwang, S. (2009): Effect of microwave irradiation on the disintegration and acidogenesis of municipal secondary sludge. Chemical Engineering Journal, 153 (1): 145-150.

Appels, L., Baeyens, J., Degreve, J. (2008): Principles and potential of the anaerobic digestion of waste-activated sludge. Progress in Energy Combustion Science, 34 (6): 755-781.

Beszédes S., László Zs., Szabó G., Hodúr C. (2009): Examination of the effect of microwave heating on the biodegradable and soluble fraction of organic matter of sludge. Annals of Faculty of Engineering Hunedoara - International Journal of Engineering, 7 (4): 87-90.

Brodie, G., Destefani, R., Schneider, P. A., Airey, L., Jacob, M. V. (2014): Dielectric properties of sewage biosolids measurement and modeling. Journal of Microwave Power and Electromagnetic Energy, 48 (3): 147-157.

Estel, L., Poux, M., Benamara, N., Polaert, I. (2017): Continuous flow.microwave reactor: where are we? Chemical Engineering and Processing, 113 (március): 56-64.

Kapcsándi V., Kovács A. J., Neményi M., Lakatos E. (2016): Investigation of non-thermal effect of microwave treatment. Acta Alimentaria, 45 (2): 224-232.

Lievonen, S. M., Roos, Y. H. (2003): Comparison of dielectric properties and non enzymatic browning kinetics around glass transition. Innovative Food Science and Emerging Technologies, 4 (3): 297-305.

Velazquez-Varela, J., Castro-Giraldez, M., Fito, P. J. (2013): Control of the brewing process by using microwave dielectric spectroscopy. Journal of Food Engineering, 119 (3): 633-639.

Venkatesh, M. S., Raghavan, G. S. V. (2004): An overview of microwave processing and dielectric properties of agri-food materials. Biosystems Engineering, 88 (1): 1-18. 